\title{
TEMPORARY SEISMOLOGICAL MEASUREMENTS IN THE POSTOJNA CAVE SYSTEM
}

\author{
OBČASNE SEIZMIČNE MERITVE V POSTOJNSKEM JAMSKEM \\ SISTEMU
}

\author{
Mladen ŽIVČIĆ ${ }^{1}$, Giovanni COSTA ${ }^{2}$, Peter SUHADOLC ${ }^{3} \&$ Stanka ŠEBELA ${ }^{4}$
}

\begin{abstract}
UDC 551.435.84:550.34.016(497.471)

Mladen Živčić, Giovanni Costa, Peter Suhadolc \& Stanka Šebela: Temporary seismological measurements in the Postojna Cave System

Karst caves are suitable places for seismological measurements because they are situated under the surface and often have lower seismic noise than locations on the surface. The idea to establish the first underground seismological station in Slovenia has led us to make preliminary seismic noise measurements in Črna Jama (part of the Postojna Cave System) in 2007. In search for further suitable stable places within the cave, we next performed seismic noise measurements, followed by a temporary accelerometer installation, near the highest point of the Velika Gora chamber in the first half of 2010. Since 7 May 2010, the seismic station is located inside the $9 \mathrm{~m}$ long artificial tunnel that was built for geophysical measurement purposes in Tartarus passage in 1931. From 27 January to 12 February 2010, the seismological station Velika Gora in Postojna Cave System (VGPJ) recorded 79 earthquakes with epicenters near Postojna. Records were especially important to determine the seismological characteristics of the $M_{L V}=3.7$ Postojna earthquake (15 January 2010) aftershocks. The station in the Tartarus tunnel (TTPJ) operated from 7 May 2010 till 21 December 2010 and recorded more than hundred earthquakes of the sequence near Ilirska Bistrica that started on 15 September 2010, with two $M_{L V}=3.5$ earthquakes and lasted till the end of the year 2010 . The aim of this study is the installation of a permanent seismic station inside the Postojna Cave System and future real-time integration of the related seismological data within the Slovenian and Italian seismological networks.
\end{abstract}

Keywords: temporary seismological measurements, seismic noise, accelerometer, Postojna Cave System, Slovenia.

\begin{abstract}
Izvleček
UDK 551.435.84:550.34.016(497.471)

Mladen Živčić, Giovanni Costa, Peter Suhadolc \& Stanka Šebela: Občasne seizmične meritve v Postojnskem jamskem sistemu
\end{abstract}

Kraške jame so primerna mesta za seizmološke meritve, saj se nahajajo pod površjem in imajo običajno nižji seizmični nemir kot mesta na površju. V želji, da bi postavili prvo podzemeljsko seizmološko postajo v Sloveniji, smo leta 2007 opravili predhodne meritve seizmičnega nemira v Črni jami (del Postojnskega jamskega sistema). Pri iskanju naslednjih ustreznih mest v jami smo v nadaljevanju v prvi polovici leta 2010 opravili meritve seizmičnega nemira ter začasno namestili pospeškometer $\mathrm{v}$ bližini najvišje točke podorne dvorane Velike Gore. Od 7. maja 2010 je potresna opazovalnica nameščena v $9 \mathrm{~m}$ dolgem umetnem tunelu, ki je bil zgrajen za geofizikalne meritve leta $1931 \mathrm{v}$ Tartarusu. Od 27. januarja do 12. februarja 2010, je seizmološka postaja na Veliki Gori v Postojnskem jamskem sistemu (VGPJ) zabeležila 79 potresov z nadžarišči pri Postojni. Podatki so bili posebno pomembni za določitev seizmoloških značilnosti popotresnih sunkov potresa $M_{L V}=3.7 \mathrm{v}$ Postojni 15. januarja 2010. Postaja v tunelu v Tartarusu (TTPJ) je delovala od 7. maja 2010 do 21 . decembra 2010 ter zabeležila več kot sto potresov sekvence pri Ilirski Bistrici, ki se je začela 15. septembra 2010 $\mathrm{z}$ dvema $M_{L V}=3.5$ potresoma in je trajala do konca leta 2010 . Namen študije je namestitev stalne potresne opazovalnice $\mathrm{v}$ Postojnskem jamskem sistemu in njena vključitev v realnem času v slovensko in italijansko seizmološko mrežo.

Ključne besede: občasne seizmične meritve, seizmični nemir, pospeškometer, Postojnski jamski sistem, Slovenija.

\footnotetext{
${ }^{1}$ Slovenian Environment Agency, Seismology and Geology Office, Dunajska 47, Ljubljana, Slovenia, e-mail: mladen.zivcic@gov.si

${ }^{2,3}$ Università degli Studi di Trieste, Dipartimento di Matematica e Geoscienze, via Weiss 2, 34128 Trieste, Italy, e-mail:costa@units.it,suhadolc@units.it

${ }^{4}$ Karst Research Institute ZRC SAZU, Titov trg 2, 6230 Postojna, Slovenia, e-mail: sebela@zrc-sazu.si
}

Received/Prejeto: 24.01.2013 


\section{INTRODUCTION}

Within the framework of the agreement on scientific cooperation between Agencija RS za okolje (Urad za seizmologijo in geologijo) from Ljubljana, Slovenia (ARSO), the ZRC SAZU (Inštitut za raziskovanje krasa) from Postojna, Slovenia (IZRK ZRC SAZU) and the Dipartimento di Matematica e Geoscienze Università degli Studi di Trieste, Italy (DMG), the Italian partner proposed to install an accelerometric station in the Postojna Cave System. In
Northern Italy there are already two underground seismic stations in continuous operation (station TRI in Grotta Gigante and station VINO in Grotta di Villanova). Karst caves are good places for such measurements due to the fact that seismic noise is lower underground than on the surface.

The aim of the study is to find a suitable place for installation of the permanent seismic station inside the

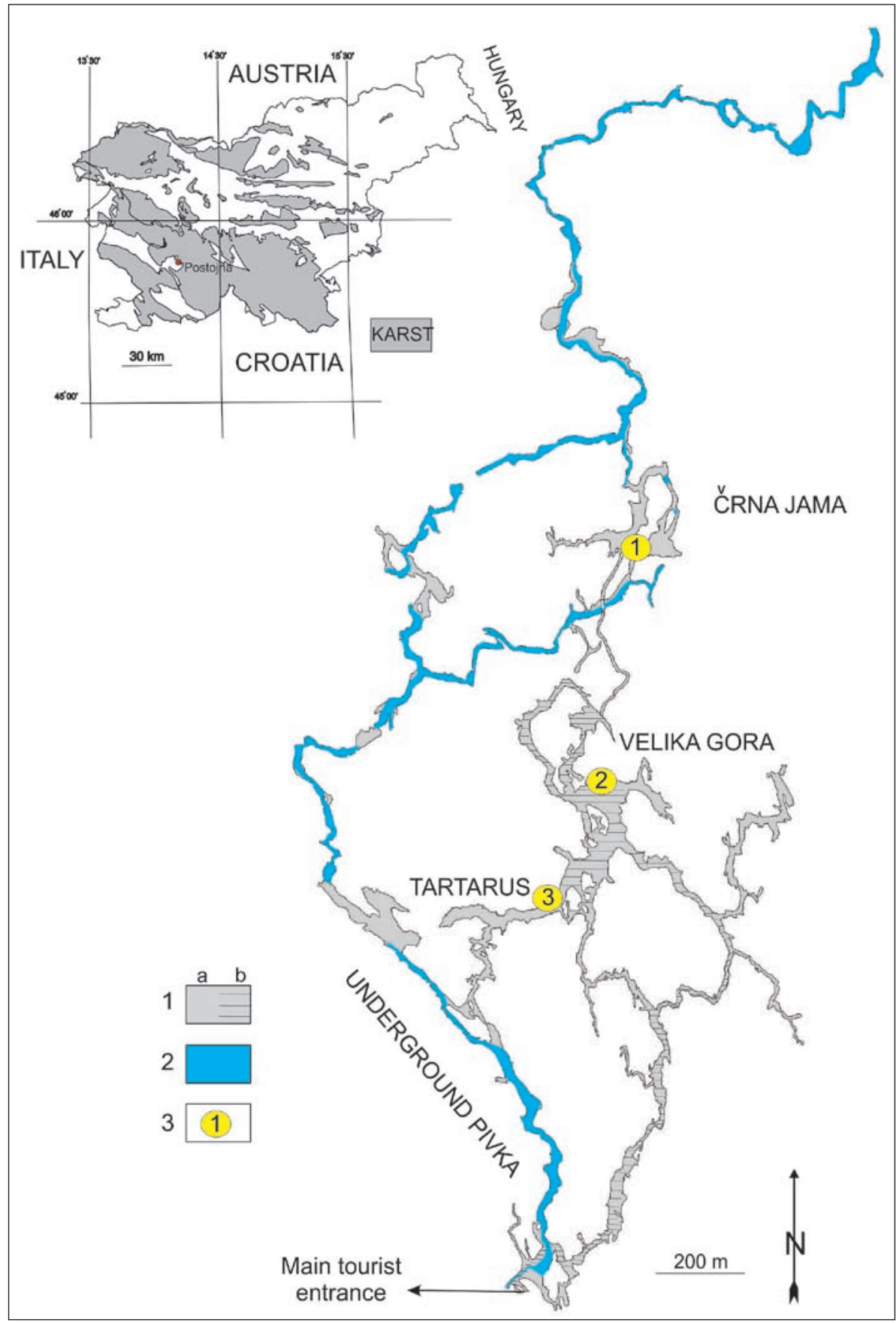

Fig. 1: The Postojna Cave System - locations of temporary seismological and seismic noise measurements.

1 - Dry cave passages (a-not frequently visited, b-tourist passages), 2 - Underground River Pivka passages, 3 - monitoring sites (1 = Črna Jama CJPJ, 2 = Velika Gora VGPJ and 3 = Tartarus tunnel TTPJ). 
Postojna Cave System and to connect the instrument in the cave with GPS and GSM antennas outside the cave for accurate timing and for on-line flow of seismological data to the data centers of the Slovenian and Italian seismic networks.

The article describes the first results of seismic noise measurements in parts of the Postojna cave system named Črna Jama (being accomplished in 2007), Velika Gora and Tartarus (measured in 2012), and of the temporary seismological recordings on Velika Gora and in the artificial tunnel in Tartarus obtained since January 2010. The first analyses have shown low seismic noise in the cave, and proved that the artificial tunnel in Tartarus is appropriate for a permanent seismological station installation.

Geophysical studies in the Postojna Cave System started already in 1932 (R. R. Grotte Demaniali di Postumia 1933). Horizontal pendulums with photographic recording were the instruments used to detect minimal variations of the vertical. They were constructed at the Astronomic Observatory in Trieste and installed in the $9 \mathrm{~m}$ long artificial tunnel, built in 1931, in the Tartarus section of the Postojna Cave System (Fig. 1). During May 1932 these instruments detected the lowering (0.0003 $\mathrm{mm}$ ) of the southern part of the rock mass due to the increased level of the underground river Pivka. The studies were important for understanding earth tides, underground karst hydrology and seismology (Carnera 1933).

In autumn of 1933 the underground river Pivka was very high and pendulum instruments in Tartarus were flooded and had to be moved to another place in the cave (R. R. Grotte Demaniali di Postumia 1934). The flood of 23 to 24 September 1933 affected a huge part of Slovenian territory. The level of the water in Tartarus reached more than $519.8 \mathrm{~m}$ above the sea. This was the highest flood in the cave in the last 100 years (Šebela 2011). Horizontal pendulums with photographic registration were removed from the cave before World War II.

\section{DESCRIPTION OF THE STUDY AREA}

Slovenia is located at the northern part of the Adriatic microplate, which is presently moving northward with a counter-clockwise rotation. A northward-oriented maximum principal stress direction has been also obtained from fault plane solutions. These reflect mostly strike-slip mechanisms along Dinaric (NW-SE) or cross-Dinaric (NE-SW) oriented faults (Poljak et al. 2010).

Slovenia is considered to have a moderate seismicity (Poljak et al. 2000). The last strong earthquakes occurred in $1998\left(M_{w}=5.6\right)$ and in $2004\left(M_{w}=5.2\right)$ in Krn Mountains in NW Slovenia (Živčić et al. 1999; Bajc et al. 2001; Pahor et al. 2006). In January 1926 (Ribarič $1982)$ the so-called Cerknica earthquake $\left(M_{S}=5.6\right)$ was well felt also in the Postojna Cave (Šebela 2010). The last strong earthquake $\left(M_{L V}=3.7\right)$ in Postojna was felt with intensity V (EMS-98) on 15 January 2010 (Jesenko et al. 2011).

The Postojna Cave System is located some $100 \mathrm{~m}$ north of the Predjama Fault zone and about 4-5 km southwest of the Idrija Fault. Both faults have a Dinaric orientation (NW-SE) and the Idrija Fault is presumably responsible for the strongest known earthquake in the area that happened on 26 March 1511 (Fitzko et al. 2005; Živčić et al. 2011a).

Being $20.570 \mathrm{~m}$ long and $115 \mathrm{~m}$ deep the Postojna Cave System is the second longest in Slovenia. The part of the cave open for visitors has electricity and other infrastructure facilities that are important and can be used for the installation of an underground seismological station.

\section{STATION SITINGS (AND RELATED NOISE MEASUREMENTS)}

The Earth is in a state of permanent shaking. Although such vibrations, called seismic noise, are imperceptible to human senses, they severely limit the sensitivity of seismic instruments and hamper their ability to record weak seismic signals. Since high-noise levels obscure weak seismic signals that we wish to record, the level of seismic noise is one of the main criteria when assessing the quality of a certain location to be used for seismological measurements. Seismic noise is present at all frequencies of interest for seismology and is caused by natural and human activity. Among the strongest natural generators of seismic noise are oceanic waves, fluctuations in barometric pres- 
sure, and wind (Bormann 2002), and their effects cannot be avoided. On the other hand noise due to human activity contains higher frequencies and propagates to shorter distances compared to long-period oceanic waves (Webb 2002), but is high close to large urban agglomerations with lots of industrial facilities and traffic.

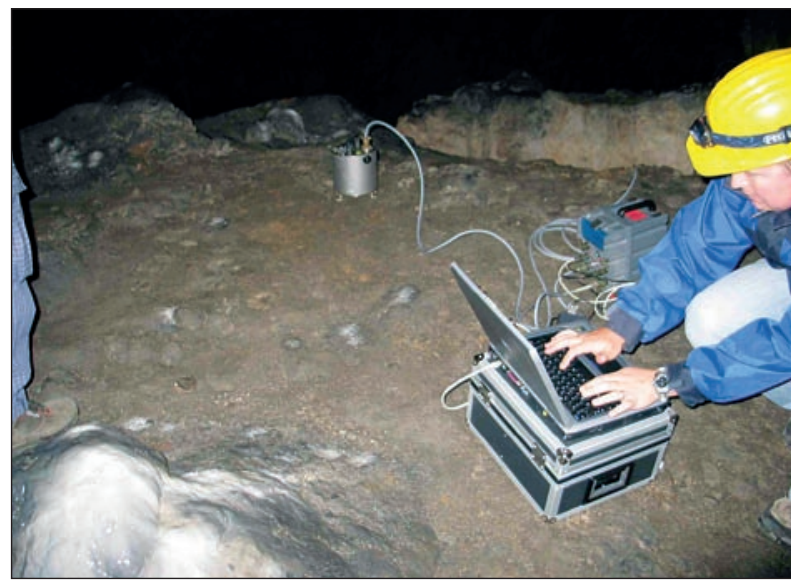

Fig. 2: Seismic noise measurements in Črna Jama in 2007 (Photo: S. Šebela).

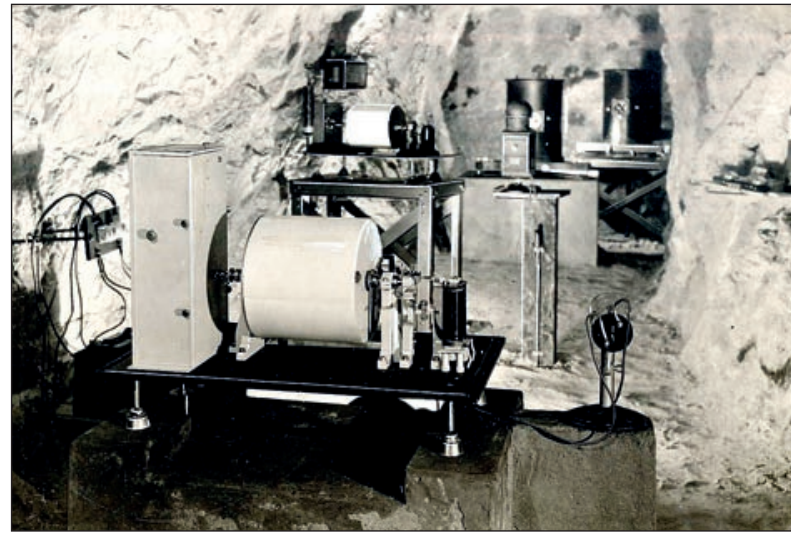

Fig. 4: Horizontal pendulums with photographic recording for the detection of minimal variations of the vertical direction, Tartarus artificial tunnel in 1932 (Carnera 1933).

The first idea was to install the subterranean seismic station close to one of the cave entrances. Thus, the Črna Jama section of the Postojna Cave System (Fig. 1) was selected for the first seismic noise measurements (Fig. 2). In order to find the best site for the seismic station installation, ARSO, IZRK ZRC SAZU and DST (now DMG), organized one-day-long seismic noise measurements in the Črna Jama cave in October 2007. Three sites have been selected, in advance, by IZRK ZRC SAZU colleagues. These sites are far enough from the part of the cave open for tourists, are near to an electric power connection, and are not far away from another cave en- trance (not used for tourist visits) in order to have the possibility to install the GPS and GSM antennas necessary to synchronize the absolute time and to transmit the data to the data centers in Ljubljana and Trieste. The measurements were made on 18 October 2007 at several sites located 10 to 50 meters from the cave entrance. The

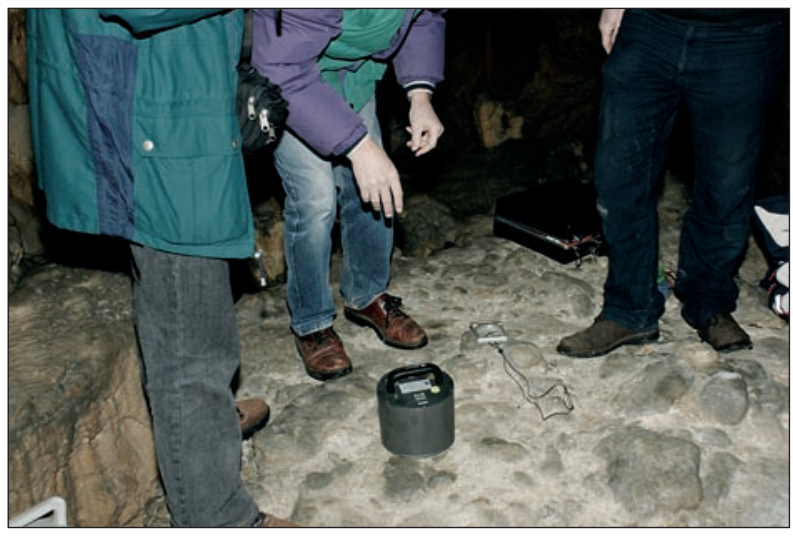

Fig. 3: Accelerometer installation at Velika Gora chamber in 2010 (Photo: S. Šebela).

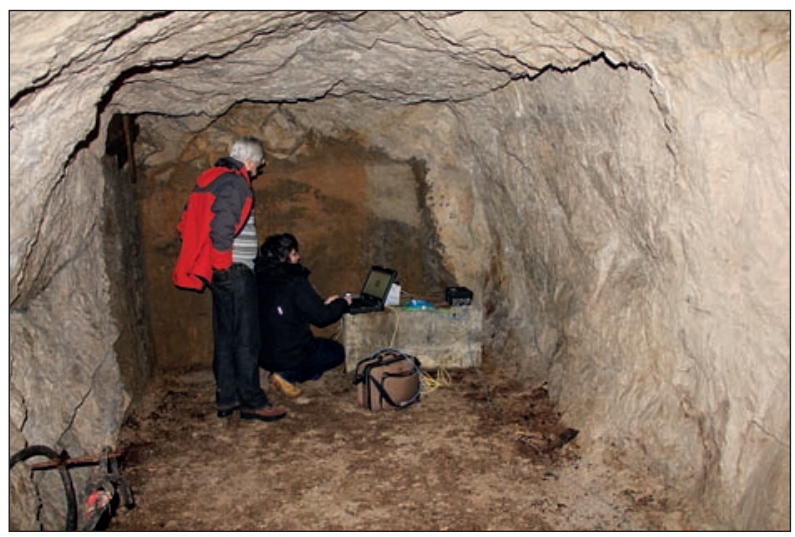

Fig. 5: Accelerometer installation in the Tartarus artificial tunnel in 2010 (Photo: S. Šebela).

place with the lowest noise level has been selected for the sensor installation. The measurements were done using Guralp CMG-40T, Lennartz LE-3D/5s and Mark IV 1s seismometers.

The construction of the seismological station in Črna Jama was delayed for some time during which the manager of the Postojnska jama d.d. company that manages the cave installed an internet infrastructure within most parts of the cave accessible to tourists. This opened new possibilities in the search for sites suitable for a station installation since the internet infrastructure can be used to carry a GPS signal to the station deep inside the cave, where seismic noise is expected to be even lower, and also to connect the stations with the seismic data 
centers in Ljubljana and Trieste for real time data transmission and station control.

In January 2010 a swarm occurred with numerous weak and moderate earthquakes having epicenters close to Postojna (Živčić et al. 2011b). Since there were no close-by seismic stations, a temporary station installation in the cave was immediately decided. On 27 January the accelerometer was installed on the top of Velika Gora at $559 \mathrm{~m}$ above sea level (Fig. 3). The position was selected in the close vicinity of a TM 71 extensiometer that has been detecting micro-tectonic displacements since 2004 (Gosar et al. 2009; Šebela et al. 2010) and where electricity was available.

On 7 May 2010 the instrument was moved to the old artificial tunnel in Tartarus (Fig. 4) at $519.8 \mathrm{~m}$ above sea level where electrical power is also available. The accelerometer with digitizer (Guralp CMG-5TD) was put on the concrete block built in 1931 (Fig. 5). The station in the tunnel (TTPJ) operated till the end of 2010.

Since the instrumental noise of the Guralp CMG-5TD accelerometer used at the Velika Gora and Tartarus sites is higher than the natural seismic noise at these two locations, it was necessary to perform additional noise measurements with more sensitive instruments. On 23 March 2012 the measurements were performed at both locations using a Lennartz LE-3D/5s seismometer and a Kinemetrics Episensor accelerometer with Earth Data PR6 recorder.

\section{RESULTS}

For each series of noise measurements, a site having a good sensor-to-ground coupling has been chosen. All the measurements have lasted for at least half an hour long, in order to stabilize the sensors and to have a long enough time series for the analysis. From the computed power spectral densities (Fig. 6), it is possible to see that the seismic noise in Postojna Cave is very low, as expected for rock sites in a cave located far away from urban areas. This holds for all the investigated sites, which show a very similar PSD in the frequency range investigated. Fig. 6 shows comparison of seismic noise measured on three locations in the Postojna Cave. The measurements were made with the same sensor but not at the same time. Signal samples of 10 minutes are compared.
Comparison of the spectra of the seismic noise measured in Tartarus tunnel in Postojna Cave and the spectra of the noise on two nearby stations situated in the caves Trieste (TRI) station located in the Grotta Gigante Cave and Villanova (VINO) station located in the Villanova Cave is presented on Fig. 7. The measurements have been made at the same time. However, the seismometers were different: STS- 1 at TRI, STS- 2 at VINO and LE-3D/5s at TTPJ.

During the measurement at Site 1 in Črna Jama, an explosion occurred nearby at 09:00:01 and was well recorded. The records have been compared with the records of JAVS seismological station (ARSO network), located not far from the cave (Fig. 8). Site 1 looks less noisy

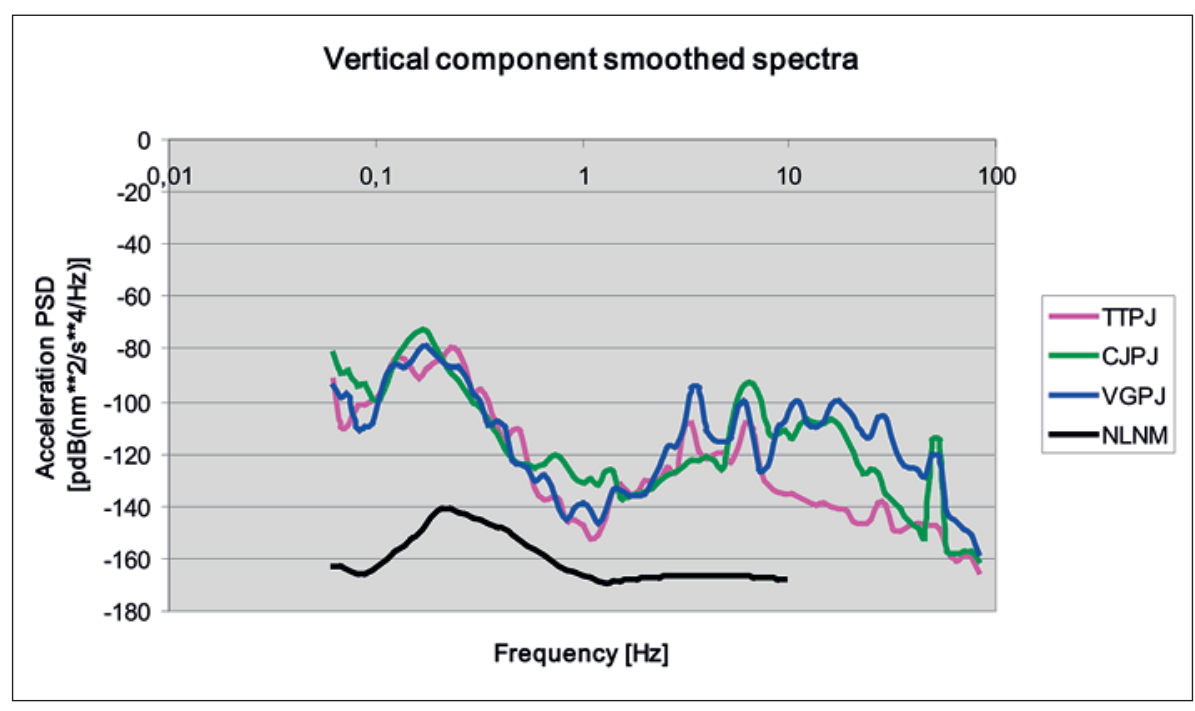

Fig. 6: Comparison of seismic noise spectra at three locations in the Postojna Cave: CJPJ Črna jama, VGPJ - Velika Gora chamber and TTPJ - Tartarus tunnel. The measurements were made with the same sensor but not at the same time. Signal samples of 10 minutes are compared. The NLNM (Peterson 1993) is given for comparison. 


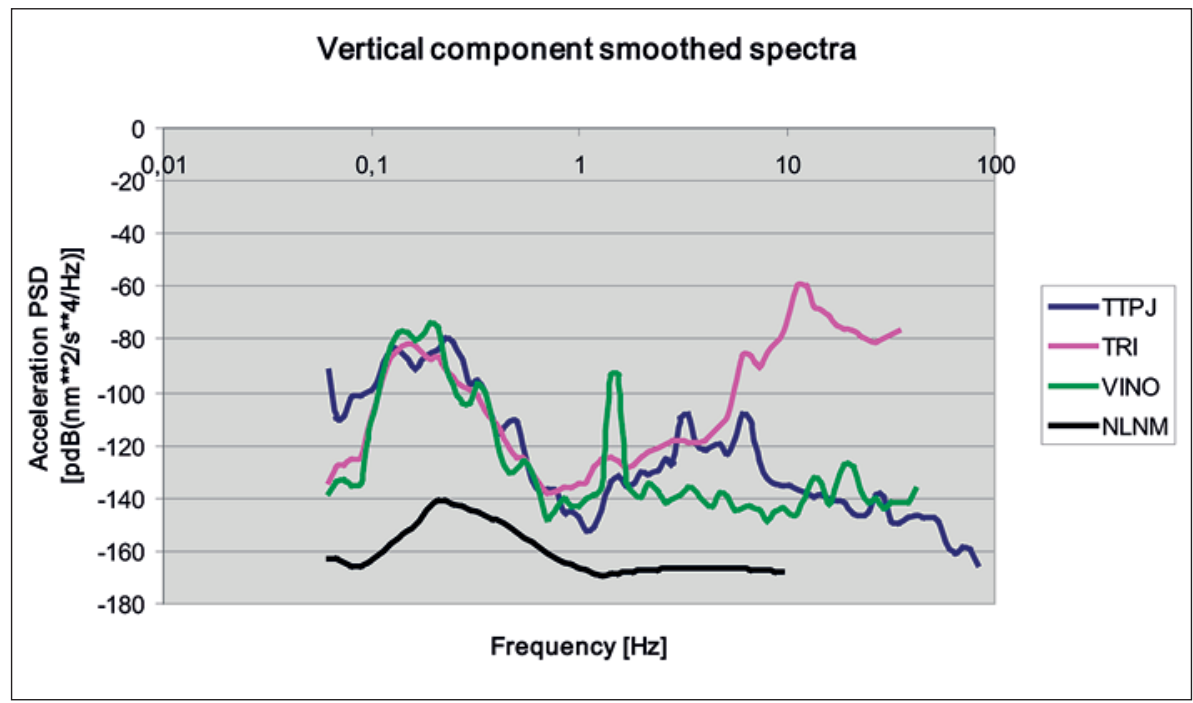

Fig. 7: Comparison of the spectra of the seismic noise measured in Tartarus tunnel (TTPJ) in Postojna Cave and the spectra of the noise at the Trieste (TRI) station located in the Grotta Gigante Cave and at the Villanova (VINO) station located in the Villanova Cave (both in Italy). The measurements were made at the same time. However, the seismometers were different: STS- 1 at TRI, STS- 2 at VINO and $L E-3 D / 5 s$ at TTPJ. The measurements were made on 23 March 2012 starting at 08:55 UTC. The NLNM (Peterson 1993) is given for comparison.

than JAVS station, although it is the noisiest site of the three considered.

During noise measurements at Velika Gora and Tartarus tunnel sites we also recorded the signal caused by the passage of the tourist train. The duration of the signal is about two minutes. The preliminary analyses show a low level of seismic noise in the cave and the artificial tunnel in Tartarus as appropriate site for permanent seismological station.

From January 27 to February 12, 2010, the seismological station VGPJ recorded 79 earthquakes with epicenters beneath Postojna (Fig. 9). The data was very use- ful to determine the seismological characteristics of the $M_{L V}=3.7$ Postojna earthquake (15 January 2010) swarm sequence. The distribution of the differences in arrival times of transversal $(\mathrm{S})$ and longitudinal $(\mathrm{P})$ waves at the VGPJ station is presented in Figure 10. The majority (95\%) of earthquakes had a Ts-Tp difference in the range of $0.07 \mathrm{~s}$ (between 1.84 and 1.91s), which helped us to constrain the size of the activated volume to about 500 meters, which is in agreement with the source size determined from the corner frequency of the P-wave spectrum assuming Brune's circular source model (Brune 1970, 1971).

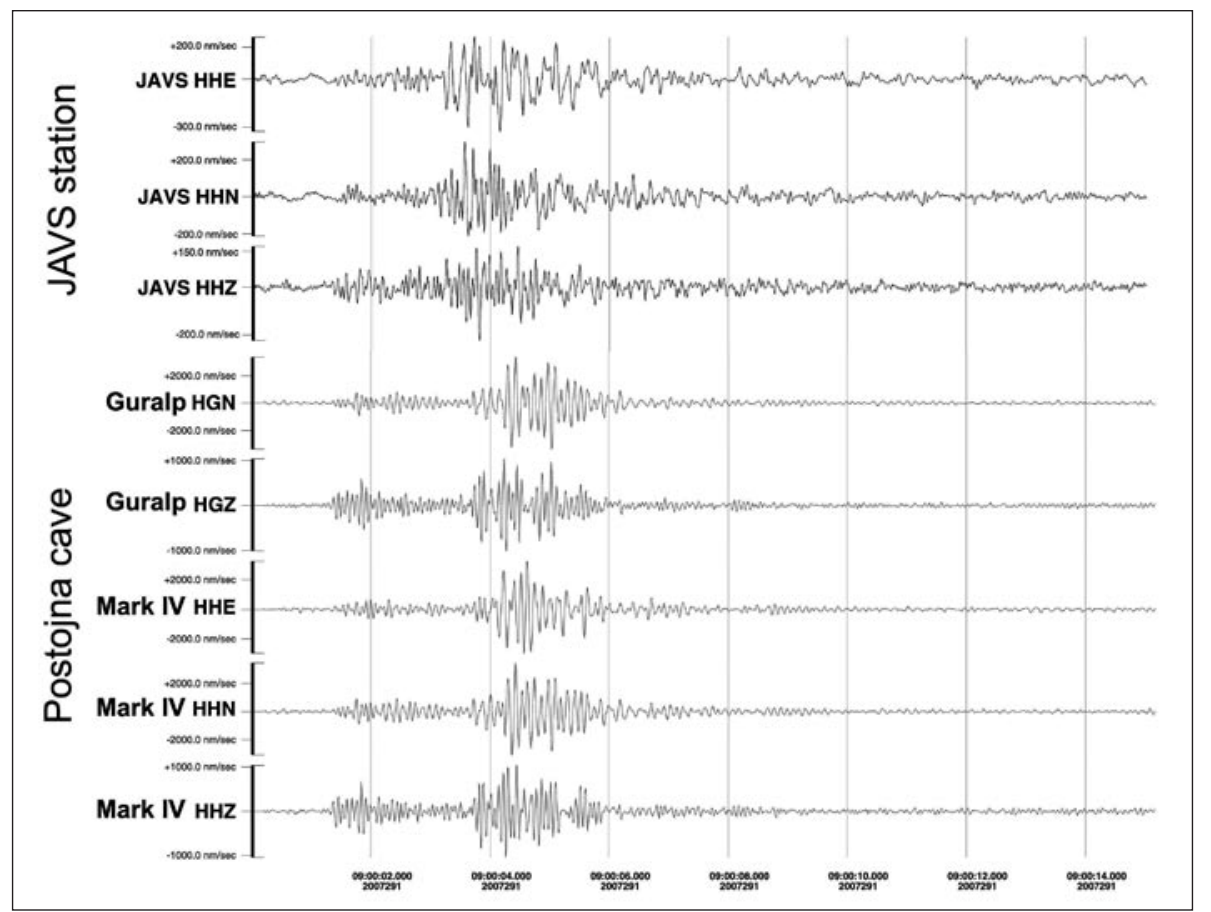

Fig. 8: Waveforms recorded by DST/DMG instruments in the Crna Jama and at the station JAVS of the Seismic Network of the Republic of Slovenia of an explosion happened during Site 1 noise measurement. For the instruments in the cave we do not have the absolute UTC time but from the Ts-Tp time difference it can be concluded that the explosion was somewhat closer to the JAVS station. 


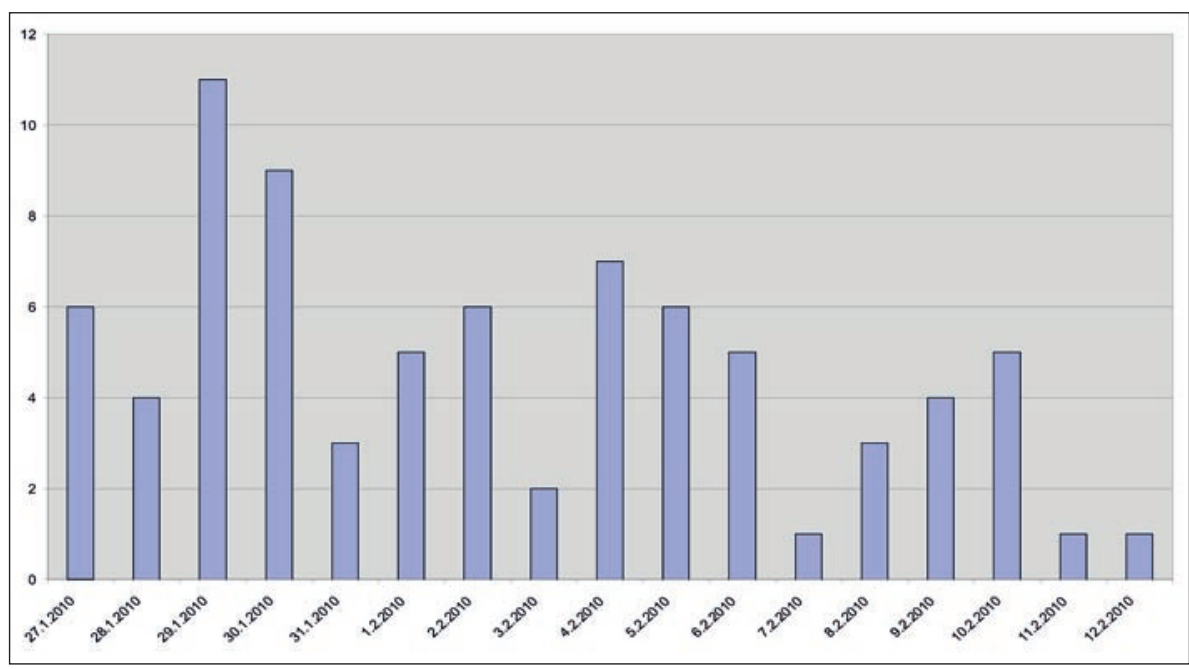

VGPJ

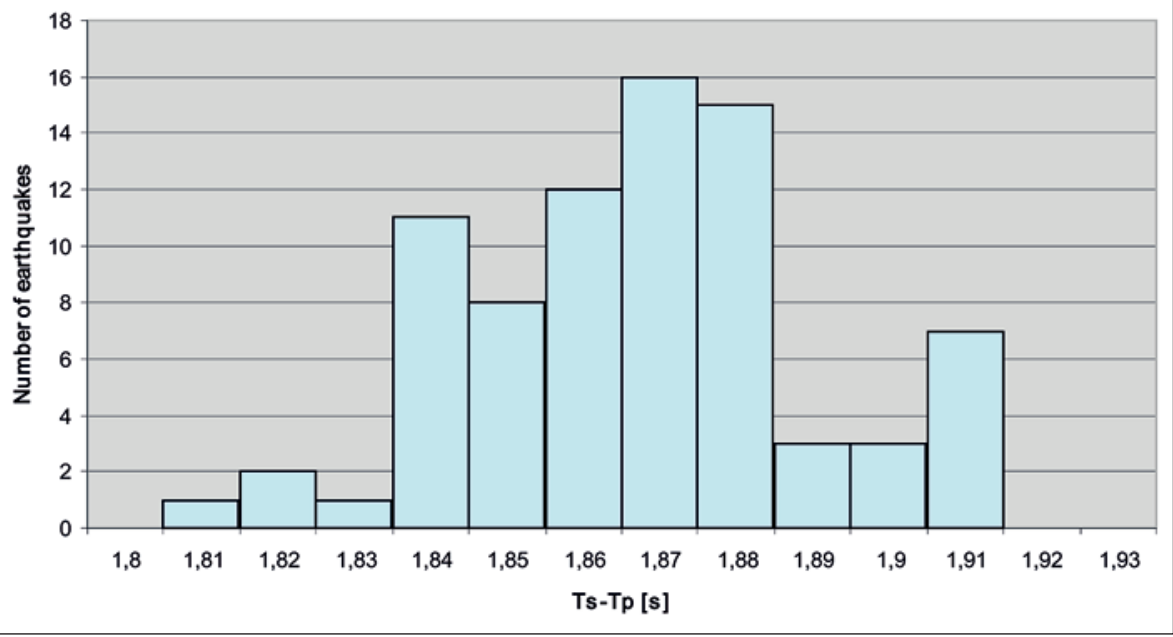

Fig. 9: Number of earthquakes with hypocenters in the vicinity of Postojna recorded on the temporary station VGPJ located in the Velika Gora chamber. On 15 January 2010 an earthquake of magnitude $M_{L V}=3.7$ followed by numerous aftershocks happened essentially underneath Postojna.

Fig. 10: Distribution of the differences in arrival times of transversal (S) and longitudinal (P) waves at station VGPJ in the Velika Gora chamber.
The TTPJ station in the Tartarus tunnel recorded more than hundred earthquakes of the sequence near Ilirska Bistrica, that started on 15 September 2010 with two $M_{L V}=3.5$ earthquakes (Čarman et al. 2011) and lasted till the end of 2010 .

\section{CONCLUSIONS}

The noise measurements performed and the temporary installations of seismic stations at various sites have shown that the location in the Tartarus artificial tunnel is appropriate and particularly suitable for the installation of a permanent seismic station. Although the site is sensitive to the high-frequency (above $20 \mathrm{~Hz}$ ) noise caused by the train passage the noise in the rest of the frequency band is sufficiently low to provide good conditions for recording local seismicity. Also, this site is close to the internet installation in the cave and with electric power already at hand. The existing concrete pier built in 1931 can be used for the sensor placement. There is also enough space in the tunnel for the supporting equipment.

For these reasons ARSO and DMG propose the Tartarus tunnel as the best possible location for the installation of the permanent seismic station in the Postojna Cave System. 


\section{ACKNOWLEDGEMENTS}

The authors are thankful to Postojnska jama d.d. (Marjan Batagelj, Ksenija Dvorščak and Stanislav Glažar) for their help. The field works of Janez Mulec (ZRC SAZU), Marko Mali and Luka Pančur (ARSO) and Lorenzo Furlan (DST) are much appreciated. This study was performed within the scientific cooperation between ARSO, IZRK ZRC SAZU and DMG. It is also part of the EPOS project (FP7 Preparatory Phase). We thank to anonymous reviewer for suggestions that have improved the paper.

\section{REFERENCES}

Bajc, J., Aoudia, A., Saraò, A. \& P. Suhadolc, 2001: The 1998 Bovec-Krn mountain (Slovenia) earthquake sequence.- Geophys. Res. Lett., 28, 9, 1839-1842.

Bormann, P., 2002: Seismic Signals and Noise.- In Bormann, P. (ed.) IASPEI New Manual of Seismological Observatory Practice (NMSOP). GeoForschungsZentrum, pp. 33, Potsdam.

Brune, J.N., 1970: Tectonic stress and the spectra of seismic shear waves from earthquakes.- J. Geophys. Res., 75, 4997-5009.

Brune, J.N., 1971: Correction.- J. Geophys. Res., 76, 5002.

Carnera, L., 1933: La stazione dei pendoli orizzontali nelle R.R. Grotte di Postumia.- Bollettino di Geodesia e geofisica, 9-10, 1933-XII, 1-13.

Čarman, M., Živčić, M. \& M. Ložar Stopar, 2011: Potresi pri Ilirski Bistrici leta 2010.- In: Gosar, A. (ed.) Potresi v letu 2010. Agencija Republike Slovenije za okolje, pp. 97-109, Ljubljana.

Fitzko, F., Suhadolc, P., Aoudia, A. \& G.F. Panza, 2005: Constraints on the location and mechanism of the 1511 Western-Slovenia earthquake from active tectonics and modeling of macroseismic data.- Tectonophysics, 404, 77-90.

Gosar, A., Šebela, S., Košták, B. \& J. Stemberk, 2009: Surface versus underground measurements of active tectonic displacements detected with TM 71 extensometers in western Slovenia.- Acta Carsologica, 38, 2-3, 213-226.

Jesenko, T., Cecić, I., Živčić, M. \& M. Čarman, 2011: Potresi v Sloveniji leta 2010.- In: Gosar, A. (ed.) Potresi $v$ letu 2010. Agencija Republike Slovenije za okolje, pp. 17-35, Ljubljana.

Poljak, M., Živčić, M. \& P. Zupančič, 2000: The seismotectonic characteristics of Slovenia.- Pure and Applied Geophysics, 157, 37-55.

Pahor, J., Kolar, J., Živčić, M. \& I. Cecić, 2006: Potres 12. julija 2004 v Krnskem pogorju (Zgornje Posočje) in opazovanje popotresne aktivnosti.- In: Vidrih, R. (ed.) Potresi v letu 2004. Agencija RS za okolje, pp. 88-94, Ljubljana.
Peterson, J., 1993: Observations and modeling of seismic background noise.- USGS Open-File Report, 93322, pp. 42, Albuquerque

Poljak, M., Gosar, A. \& M. Živčić, 2010: Active tectonics in Slovenia: GeoActa, 3, 15-24.

R. R. Grotte demaniali di Postumia, 1933: Relazione del consiglio d'amministrazione alle loro eccellenze $i$ ministri delle corporazioni e delle finanze sull'andamento dell'azienda dal $1^{\circ}$ gennaio al 31 dicembre 1932. R. R. Grotte demaniali di Postumia, XI, pp. 57, Postumia.

R. R. Grotte demaniali di Postumia, 1934: Relazione del consiglio d'amministrazione alle loro eccellenze $i$ ministri delle corporazioni e delle finanze sull'andamento dell'azienda dal $1^{\circ}$ gennaio al 31 dicembre 1933. R. R. Grotte demaniali di Postumia, XII, pp. 50, Postumia.

Ribarič, V., 1982: Seismicity of Slovenia - Catalogue of Earthquakes (792 A.D. - 1981).- SZ SRS, Publication, A, 1-1, pp. 650, Ljubljana.

Šebela, S., 2010: Effects of earthquakes in Postojna cave system.- Acta Carsologica, 39/3, 597-604.

Šebela, S., Vaupotič, J., Košták, B. \& J. Stemberk, 2010: Direct measurement of present-day tectonic movement and associated radon flux in Postojna cave, Slovenia.- Journal of Cave and Karst Studies, 72, 1, 21-34.

Šebela, S., 2011: Exceptional natural events in Postojna and Predjama Cave Systems.- Annales (Ser. Hist. Nat), 21, 1, 87-94.

Webb, S. C., 2002: Seismic Noise on Land and on the Sea Floor.- In: Lee, W.H.K. et al. (eds.) International Handbook of Earthquake and Engineering Seismology. Part A, Academic Press, pp. 305-318, Amsterdam, London.

Živčić, M., Cecić, I., Gosar, A. \& P. Zupančič, 1999: Potres 12. aprila 1998 v Zgornjem Posočju - osnove značilnosti.- In: Lapajne, J. (ed.) Potresi v letu 1998. Uprava RS za geofiziko, pp. 49-64, Ljubljana. 
Živčić, M., Čarman, M., Gosar, A., Jesenko, T. \& P. Živčić, M., Čarman, M. \& M. Ložar Stopar, 2011b: Potres Zupančič, 2011a: Potresi ob Idrijskem prelomu.Idrijski razgledi, LVI, 1, 119-126.

15. januarja 2010 pri Postojni. In: Gosar, A. (ed.) Potresi v letu 2010. Agencija Republike Slovenije za okolje, pp. 76-86, Ljubljana. 